\title{
Study of The Relationship Between Academic Level and Ability of Third Grade Elementary School Students and Their Participation in Classroom Activities
}

\author{
Hamid Rafiee Afousi
}

Bachelor of Science in Education, Farhangian University, Tehran, Iran.

\begin{tabular}{|c|c|}
\hline ARTICLE INFO & ABSTRACT \\
\hline $\begin{array}{l}\text { Keywords: } \\
\text { Participation in The } \\
\text { Classroom } \\
\text { Students' Ability } \\
\text { Schizoid }\end{array}$ & $\begin{array}{l}\text { This study was conducted to determine the relationship between level } \\
\text { of ability and participation in the classroom in elementary school } \\
\text { students in Aligudarz. To achieve the purpose of this study, active } \\
\text { students were identified using checklists and then by performing } \\
\text { functional tests, their level of ability is measured. The statistical } \\
\text { population of the study consisted of the third grade students of } \\
\text { Aligudarz city in the academic year of 1396-97. Then, } 50 \text { of them } \\
\text { were selected through a targeted sampling method. The findings of } \\
\text { this study indicate that there is a relationship between the level of } \\
\text { students' ability and their participation in the classroom. For this } \\
\text { reason, dynamic students in the classroom are progressing, but non- } \\
\text { dynamic students do not make much progress. By using the methods } \\
\text { outlined in this text, student participation increases. }\end{array}$ \\
\hline
\end{tabular}

\section{Introduction}

Active participation of students in the process of teaching and learning is one of the important issues that attracted the attention of many researchers, because participation in the teaching process causes mental involvement and increased learning.

Children are the most valuable capital for society.

Education in a childhood, the time of the formation of personalities and the creation of different habits, builds the future of the individual and society. So paying attention to children's issues will make society progress, and neglecting their problems will cause irreparable damage.

The third childhood is between 6 and 12 years old. Which is known as the pre-school course. This is the beginning of the formal education of children, and in this course children learn to read, write and count.

Today one of the important factors in learning is the participation of students in class activities and their active role. For this reason, passive students are not successful in learning, and they also have difficulty in social skills. In these cases, attracting student participation is a good strategy. Which causes a fundamental change in the student. According to evidence, there is a link between the level of students' ability and their participation in the classroom. For this reason, in this paper, we examined the relationship between these two variables in the schools of Aligudarz.

\section{Research Questions}

Is there a relationship between students' participation in the classroom and their level of knowledge and ability?

Is lack of student participation in class activities due to their scientific weakness?

Does the student participation in the class affect their learning?

* Corresponding Author E-Mail Address: mobilerafiee@yahoo.com 


\section{Active learning and collaborative learning}

In the new teaching methods, we try to convert the learning process from passive to active. What is active learning? Active learning is the kind of learning that a student produces the concept. Conversely, in learning to pass through, the student must maintain ready-made concepts. In active learning, learning content and understanding is important. This type of learning is only achieved through direct involvement with the problem. But in passive learning, emphasis is on reading and retaining them.

In Paul's words, passive learning is the learning of a "banking" model. The student gradually stores the material in his mind and returns them to the exam; therefore, the best score is given to anyone who can safely redeem the money deposited to the memory card completely!

In passive learning, the teacher teaches the content and concepts, therefore, he uses the lecture method. While in the active learning style, the teacher is the learning guide and is the source of the question.

In active learning, students are tasked with activities such as: "collecting information", "ask and tell your colleagues", "build", "test".

\section{Research Methodology}

The present study is an applied research type. And it uses pre-test and post-test of the constructed teacher. The researcher used a targeted random sampling method to do this research.

First, a pre-made test is taken from all students, and then isolated students are identified by using the check list. Then they will increase their participation by using the methods of participation, and then the retrospective test will be performed.

\section{Statistical Society:}

The community of students is the third elementary school in Aligudarz, selected by targeted sampling.

\section{Analyze}

At first, students were taken from a pre-made functional test from the first chapter of science. That results are as follows:

\begin{tabular}{|l|c|c|c|}
\hline \multicolumn{1}{|c|}{ Response level } & Grade & Number & Percent \\
\hline very good & A & 17 & 34 \\
\hline good & B & 21 & 42 \\
\hline acceptable & C & 7 & 14 \\
\hline Need to more try & D & 5 & 10 \\
\hline
\end{tabular}

Then they were identified using the checklist for non-active students in the science class. Which was 14 people. The results of the 14 were remarkable, as follows

\begin{tabular}{|l|c|c|c|}
\hline \multicolumn{1}{|c|}{ Response level } & Grade & Number & Percent \\
\hline very good & A & 1 & 7 \\
\hline good & B & 2 & 14 \\
\hline acceptable & C & 6 & 43 \\
\hline Need to more try & D & 5 & 36 \\
\hline
\end{tabular}

We conclude according to the results of the test. Students who have received the lowest level in the test have often not participated in classroom activities. 
It can be said: These students cannot participate in class action due to scientific weakness, and they are marginalized in the classroom and do not pay attention to the discussion.

From the case study, people who rank very well and well have been received that these people did not participate due to prior knowledge and lack of interest in the class.

Getting good grades is because of their interest in learning and previous knowledge in the classroom. By enhancing their motivational activities, they should raise their interest in participating in the classroom and use them to educate poor students.

After doing the initial test strategies for increasing students' participation in the classroom were implemented for one month. Then a post-test was conducted in the classroom, whose results are as follows.

\begin{tabular}{|l|c|c|c|}
\hline \multicolumn{1}{|c|}{ Response level } & Grade & Number & Percent \\
\hline very good & A & 19 & 38 \\
\hline good & B & 25 & 50 \\
\hline acceptable & C & 5 & 10 \\
\hline Need to more try & D & 1 & 2 \\
\hline
\end{tabular}

The results of the 14 previous ones were as follows

\begin{tabular}{|l|c|c|c|}
\hline \multicolumn{1}{|c|}{ Response level } & Grade & Number & Percent \\
\hline very good & A & 3 & 21 \\
\hline good & B & 7 & 50 \\
\hline acceptable & C & 3 & 21 \\
\hline Need to more try & D & 1 & 8 \\
\hline
\end{tabular}

So we can conclude that: attracting the attention of poor students and increasing their participation will increase their learning and the participation of strong students also helps poor students and their own. When the success has not been found, it can be said that the influence of other factors has been

\section{Conclusion}

So, it can be said that the partnership between the students in the classroom and their level of knowledge and abilities has a reciprocal relationship. In many cases, lack of student participation in classroom activities is due to their scientific weakness. And the participation of students in class activities affected their learning.

In other words, we can conclude from the results of the above research that students who are less involved in the classroom have a lower academic level and less ability.

But usually this scientific weakness causes the lack of participation in the classroom. And then it will reduce the level of science.

If this item is not checked, this person will generally lose confidence in that lesson and he cannot succeed. But if these people are encouraged to engage in classroom activities by using methods such as being responsible, group activity and role-playing in the group, attracting teaching methods, etc. They can participate as an active element in the class, and learn to work effectively using this method.

In the end, it can be said that the relationship between the level of ability and the participation of a reciprocal relationship. 


\section{References}

Fazli Khani, Manouchehr (2001), Academic Guide to Participatory and Active Learning, School Publications, Tehran.

Pakiseh, Ali, (2005), Investigating the Effect of Participatory Learning on Academic Achievement and Self-Concept of Shiraz Students, Master's thesis, Shiraz University, Shiraz.

Qaltash, Abbas (2004), Investigating the Effect of Participatory Learning on the Development of Social Skills of the 5th Students of Kerman City, Master's Thesis, Tarbiat Moalem University of Tehran.

Salehi, Vahid and Seyyed Mohammad Reza Safavi (2009), Participation, Learning Foundation in Online Learning Environments, Fourth National Conference and First International Conference on Electronic Education, Tehran.

Shafi Abadi, Abdullah (1996), Child Guidance and Advice, Fifth Edition, Publication, Tehran.

Slavin, Robert (1992), Collected Research on Participatory Learning, Fatemeh Faghihi Translation, Quarterly Journal of Teaching, Tehran. 